\title{
PENGARUH KADAR POLIETILEN GLIKOL (PEG) 400 TERHADAP PELEPASAN NATRIUM DIKLOFENAK DARI SEDIAAN TRANSDERMAL PATCH TYPE MATRIKS
}

\author{
Aditya Fridayanti ${ }^{1)}$, Esti Hendradi ${ }^{2)}$, Isnaeni ${ }^{2)}$ \\ Kelompok Bidang Ilmu Farmasetika, Fakultas Farmasi, Universitas Mulawarman, Samarinda \\ e-mail:dietya_fy@yahoo.com ${ }^{1)}$ \\ Departemen Farmasetika, Fakultas Farmasi, Universitas Airlangga, Surabaya ${ }^{2)}$
}

\begin{abstract}
The sodium diclofenac realeased from transdermal patch of combination of EC N-2O and PVP K-30 with ratio 6:4 with plasticizer PEG 400 5\% (formula 1), PEG 400 10\% (formula 2) and PEG $40020 \%$ (formula 3) was investigated. The percentage of moisture contents was calculated as a difference between initial and final weight with respect to final weight. The homogeneity of patch surface was determined using fluorescence microscope and scanning electron microscope (SEM). Released test using dissolution apparatus were carried out in 500 $m L$ of phosphate buffer saline pH $7.4 \pm 0.05$ at temperature $37 \pm 0.5^{\circ} \mathrm{C}$ with speed of swirl 50 rpm. Results were analyzed by statistic programmed of SPSS using one way analysis of variance with degree of believed 95\% $(\alpha=0,05)$, showed that that the combination of EC N20 and PVP K-30 at ratio 6:4 with plasticizer PEG $4005 \%$ was the best choice for manufacturing transdermal patch based on physicochemical and the release profile.
\end{abstract}

Keyword: $\quad$ Released Diclofenac sodium, plasticizer, combination matrix of EC N-20 and PVP K-30, polyetilen gliko 400, and plasticizer.

\begin{abstract}
ABSTRAK
Telah dilakukan penelitian pelepasan sodium diklofenak dari transdemal Patch kombinasi matriks EC N-20 dan PVP K-30 dengan rasio 6:4 dan plasticizier PEG $4005 \%$ (formula 1), PEG 400 10\% (formula 2), dan PEG $40020 \%$. Persentase kadar air dihitung sebagai perbedaan antara berat awal dan akhir. Homogenitas dari permukaan Patch di determinasi menggunakan Mikroskop flourescence dan SEM. Uji pelepasan dilakukan menggunakan alat uji dissolusi dalam $500 \mathrm{~mL}$ larutan salin fosfat buffer $\mathrm{pH} 7.4 \pm 0.05$ pada suhu $37 \pm 0.5^{\circ} \mathrm{C}$ dengan kecepatan pengadukan $50 \mathrm{rpm}$. Hasil di analisis menggunakan program statistik SPSS analisis one way variance (ANAVA) dengan tingkat kepercayaan 95\% $(\alpha=0,05)$, menunjukkan bahwa kombinasi dari EC N-20 and PVP K-30 pada rasio 6:4 dengan plasticizer PEG 400 5\% merupakan pilihan terbaik untuk industri Patch transdemal berdasarkan fisikokimia dan profil pelepasan.
\end{abstract}

Kata Kunci: Pelepasan sodium diklofenak, plasticizer, matriks kombinasi dari EC N-20 and PVP K-30, polyetilen gliko 400, plasticizer 
Pengaruh kadar polietilen glikol (peg) 400 terhadap Pelepasan natrium diklofenak dari sediaan Transdermal patch type matriks

\section{PENDAHULUAN}

Beberapa tahun terakhir ini, rute pemberian transdermal menjadi fokus penelitian dalam penghantaran yang inovatif. Salah satu bentuk sediaan yang diberikan secara transdermal adalah bentuk sediaan patch. Patch merupakan bentuk sediaan yang bertujuan untuk menghantarkan obat melewati kulit masuk ke dalam sirkulasi darah $^{6}$. Patch akan efektif apabila obat yang dibawa dapat berpenetrasi ke dalam kulit dan mencapai target ${ }^{3}$. Syarat suatu obat dapat dibuat dalam bentuk sediaan patch yaitu memiliki dosis kurang dari 20 mg per hari, waktu paruh pendek, tidak memberikan efek toksik pada kulit, berat molekul kurang dari 500 daltons, memiliki koefisien partisi 1-3, serta kelarutan dalam minyak dan air lebih besar dari $1 \mathrm{mg} / \mathrm{mL}^{5}$.

Beberapa obat jika diberikan dalam bentuk oral akan mengalami first pass metabolisme dan memberikan efek samping berupa iritasi pada lambung, sehingga lebih baik bila diberikan dalam bentuk sediaan patch. Patch lebih dipilih dibandingkan pemberian secara intravena karena tidak menimbulkan rasa sakit, kerusakan jaringan dan menghilangkan rasa takut pasien. Salah satu obat tersebut adalah natrium diklofenak. Frekuensi pemberian natrium diklofenak yang tinggi, karena mengalami first pass metabolisme menyebabkan meningkatnya resiko efek sampingnya. Untuk mengatasi hal ini, sebagai alternatif dipilih bentuk sediaan transdermal patch ${ }^{5}$.

Natrium diklofenak merupakan salah satu obat golongan non steroid anti-inflamasi (NSAIDs) yang secara luas digunakan untuk menghilangkan rasa sakit dan inflamasi. Pemilihan natrium diklofenak karena lebih stabil dibandingkan kalium diklofenak yang lebih reaktif. Efek terapi dan efek samping yang sering ditimbulkan obat ini dapat dijelaskan berdasarkan penghambatan biosintesis prostaglandin, yaitu dengan menghambat kerja enzim siklooksigenase yang berperan dalam pembentukan prostaglandin ${ }^{1}$.

Sediaan transdermal natrium diklofenak yang beredar di pasaran saat ini lebih banyak dalam bentuk cairan, gel atau krim dan diaplikasikan langsung pada kulit. Obat yang diaplikasikan akan berpenetrasi menembus kulit memberikan efek farmakologi untuk jangka waktu pendek. Oleh sebab itu, akan dikembangkan bentuk sediaan patch natrium diklofenak untuk memperbaiki kemampuannya, sehingga dapat diberikan dalam jangka waktu lama dan pemberiannya mencapai sistemik ${ }^{5}$.

Komponen patch harus stabil secara fisika dan kimia dan tidak boleh mempengaruhi stabilitas obat serta bahan tambahan yang lain. Patch dengan tipe matriks tersusun dari lapisan backing membrane, polimer pembawa obat, adhesive, dan release liner. Backing membrane memiliki persyaratan yang berbeda-beda tergantung sistem yang digunakan. Secara umum, semua backing membrane harus menunjukkan laju pengantaran kelembaban yang rendah dan sifat mekanik seperti fleksibilitas dan daya rentang yang baik, saat digunakan pada kulit dan selama penyimpanan setelah pembuatan. Bahan yang sering digunakan sebagai backing membrane adalah polyolefins, multilayer films, polyesters dan elastomers. Release liner biasanya menggunakan bahan yang serupa (polyethylene, polyesters) dilapisi dengan silicone atau fluorocarbon. Bahan adhesive diperlukan supaya patch dapat ditempelkan pada permukaan kulit. Rasa gatal, iritasi, adanya sisa dan trauma pada kulit setelah patch dilepaskan harus diminimalkan dengan pemilihan adhesive yang tepat. Hal lain yang harus diperhatikan dalam pemilihan bahan 
Pengaruh kadar polietilen glikol (peg) 400 terhadap Pelepasan natrium diklofenak dari sediaan Transdermal patch type matriks

adhesive adalah kelarutan dan stabilitas obat atau bahan tambahan dalam bahan adhesive dan kemampuan lekatnya. Bahan adhesive yang sering digunakan yaitu polyisobutylene-, polyacrylate-, dan polysiloxane-based adhesives. 5 . Polimer seperti polyisobutylane, silicone elastomer dan polyvinyl alcohol atau polivinilpirolidon sering digunakan dalam tipe matriks sebagai pembawa obat. Cosolvent dapat ditambahkan untuk meningkatkan kelarutan obat. Penambahan plasticizer juga membantu meningkatkan laju pelepasan obat ${ }^{2,5}$.

Plasticizer yang digunakan dalam penelitian ini adalah polietilenglikol (PEG) 400. Polietilen (PEG) 400 merupakan salah satu polimer dari polietilenglikol yang berwujud cair dalam suhu ruangan dengan struktur $\mathrm{HO}-\left(\mathrm{O}-\mathrm{CH}_{2}-\mathrm{CH}_{2}\right) \mathrm{n}-\mathrm{OH}$ dengan $\mathrm{n}$ berkisar antara 8 atau 9. Dengan struktur yang khas seperti ini membuat PEG misibel dengan air melalui ikatan hidrogen. Bagian hidrokarbon yang bersifat hidrofobik dari struktur polietilenglikol (PEG) 400 membantu memutuskan ikatan hidrogen diantara molekul air sehingga mengurangi interaksi intermolekul air menyebabkan momem dipol (kepolaran) air menjadi menurun dan komponen hidrofobik dapat masuk ke dalam rongga antar molekul air. Polietilenglikol (PEG) 400 stabil secara kimia dan memiliki toksisitas yang relatif rendah ${ }^{4}$.
Berdasarkan uraian di atas, maka dalam penelitian ini ingin diketahui bagaimana pengaruh kadar polietilenglikol (PEG) 400 pelepasan natrium diklofenak $100 \mathrm{mg} / 50 \mathrm{~cm}^{2}$ dari matriks kombinasi polimer etil selulosa (EC) $\mathrm{N}-20$ dan polivinilpirolidon (PVP) K-30, ditambahkan menthol sebagai enhancer dengan kadar $1 \%$ dan polietilen glikol 400 sebagai plasticizer dengan kadar 5\%, 10\% dan $20 \%$.

\section{METODE PENELITIAN}

\section{Bahan}

Bahan-bahan yang digunakan dalam penelitian apabila tidak disebut lain memiliki kemurnian pharmaceutical grade. Bahan utama yang digunakan dalam penelitian ini adalah natrium diklofenak, polivinilpirolidon (PVP $\mathrm{K}-30$ ), etil selulosa (EC N-20), polietilen glikol (PEG) 400 , menthol dari PT.Bratachem.

\section{Persiapan}

Sediaan patch natrium diklofenak tipe matrix controlled dengan perbandingan polimer yang berbeda direncanakan dibuat untuk menghasilkan berat rata-rata 0,500 gram dengan diameter $3 \mathrm{~cm}$, luas permukaan $7.065 \mathrm{~cm}$

\begin{tabular}{cccc} 
Tabel 1. Tabel Rancangan formula sediaan patch Natrium Diklofenak \\
\cline { 2 - 4 } Bahan & \multicolumn{3}{c}{ Konsentrasi $\left(\mathrm{mg} / 7.065 \mathrm{~cm}^{2}\right)$} \\
\cline { 2 - 4 } & Formula 1 & Formula 2 & Formula 3 \\
\hline Natrium diklofenak & 14.13 & 14.13 & 14.13 \\
EC N-20 & 273.52 & 258.52 & 266.61 \\
PVP K-30 & 182.35 & 172.70 & 114.26 \\
Polietilen glikol 400 & 25 & 50 & 100 \\
Menthol & 5 & 5 & 5 \\
\hline
\end{tabular}




\section{Cara pembuatan :}

PVP K-30 dan EC N-20 masing-masing dilarutkan dalam etanol $96 \%$ hingga larut. Larutan PVP K-30 dimasukkan ke dalam larutan EC N-20 sambil diaduk hingga tercampur merata. Sebelumnya telah dibuat larutan menthol dengan cara ditimbang menthol sejumlah 0,0500 gram, dilarutkan dalam etanol $96 \%$ hingga tepat 100,0 mL. Untuk masing-masing formula, digunakan 1,0 mL larutan menthol dituang ke dalam natrium diklofenak, diaduk sampai terlarut. Campuran natrium diklofenak dan menthol dimasukkan ke dalam campuran PVP K-30 dan EC N-20. Pengadukan dilakukan secara hati-hati dan merata hingga semua bahan tercampur. Polietilen glikol 400 dan sisa larutan etanol $96 \%$ ditambahkan sedikit demi sedikit sambil terus dilakukan pengadukan hingga homogen. Setelah homogen, sediaan dituang ke dalam cetakan. Sediaan patch natrium diklofenak dikeringkan dalam lemari asam.

\section{Pemeriksaan Organoleptis Sediaan}

Pemeriksaan organoleptis sediaan patch natrium diklofenak dilakukan secara visual meliputi bentuk, warna dan bau.

\section{Uji Moisture Content (MC)}

Sediaan patch natrium diklofenak dikeringkan dalam lemari asam kemudian ditimbang, dimasukkan ke dalam desikator yang telah diisi silica gel dan didiamkan selama 24 jam. Setelah 24 jam, sediaan patch natrium diklofenak dikeluarkan dari deksikator untuk ditimbang kembali. Prosentase moisture content (\%MC) dihitung dari rumus:

$$
\% M C=\frac{w_{1}-w_{2}}{w_{2}} \times 100 \%
$$

$\mathrm{w}_{1}=$ berat sediaan patch natrium diklofenak sebelum dimasukkan ke dalam desikator.

$\mathrm{w}_{2}=$ berat sediaan patch natrium diklofenak setelah dimasukkan ke dalam desikator.

\section{Uji in vitro Pelepasan}

Bejana disolusi dengan media larutan dapar fosfat salin $7.4 \pm 0,05$ sebanyak $500,0 \mathrm{~mL}$ yang terlebih dahulu dipanaskan sampai mencapai temperatur percobaan $37 \pm$ $0,05^{\circ} \mathrm{C}$. Sediaan patch natrium diklofenak diletakkan pada dasar benjana. Pengaduk tipe dayung dipasang pada ketinggian 2,5 $\mathrm{cm}$ di atas sediaan dan diputar dengan kecepatan $50 \mathrm{rpm}$ dan segera dicatat sebagai menit ke nol. Pada setiap menit ke $30,60,90,120,150,180,210,240,270$, 300, 330, 360 diambil cuplikan sebanyak $5,0 \mathrm{~mL}$ di tengah-tengah antara permukaan media disolusi dan bagian atas daun dayung, tidak lebih dari satu $\mathrm{cm}$ dari dinding bejana. Setiap kali pengambilan cuplikan, bejana disolusi ditambah larutan

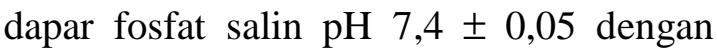
jumlah dan temperatur yang sama pula. Dilakukan koreksi terhadap kadar 5,0 mL yang diganti dengan larutan dapar yaitu dengan menambahkan kadar dari menit sebelumnya (kadar dikalikan 5) ke dalam kadar pada menit selanjutnya pada media $500,0 \mathrm{~mL}$. Konsentrasi natrium diklofenak dalam cuplikan dihitung dengan menggunakan persamaan regresi kurva baku natrium diklofenak dalam dapar fosfat salin $\mathrm{pH} 7,4 \pm 0,05$.

\section{HASIL DAN PEMBAHASAN}

Hasil pemeriksaan organoleptis sediaan patch natrium diklofenak dapat dilihat pada Tabel 2 dan Gambar 1. Dari hasil pemeriksaan organoleptis sediaan dapat dilihat bahwa sediaan patch natrium 
Pengaruh kadar polietilen glikol (peg) 400 terhadap Pelepasan natrium diklofenak dari sediaan Transdermal patch type matriks

diklofenak berwarna putih, kaku sampai rapuh dan tidak berbau.

Berdasarkan uji organoleptis, menunjukkan bahwa formula 1, 2 dan 3 tidak memiliki perbedaan yang bermakna, memberikan konsistensi yang kaku tapi agak rapuh dan berwarna putih transparan.

Hasil pemeriksaan uji moisture content (MC) dari masing-masing formula sediaan patch natrium diklofenak dapat dilihat pada Gambar 2.

Berdasarkan hasil perhitungan dari data yang diperoleh pada uji moisture content, diperoleh nilai \% moisture content meningkat seiring dengan peningkatan konsentrasi PEG 400.

Data uji pelepasan natrium diklofenak pada optimasi PEG 400 menunjukkan harga fluks untuk kadar 5\% sebesar $57.197 \pm$
$10.727 \mu \mathrm{g} / \mathrm{cm}^{2} / \mathrm{menit}^{1 / 2}$, kadar $10 \% 62.409$ $\pm 1.944 \mu \mathrm{g} / \mathrm{cm}^{2} / \mathrm{menit}^{1 / 2}$ dan kadar $20 \%$ $67.266 \pm 2.815 \mu \mathrm{g} / \mathrm{cm}^{2} / \mathrm{menit}^{1 / 2}$. Dari data tersebut, kemudian dilakukan analisa statistika Anova one way. Hasil analisa menunjukkan bahwa nilai $F_{\text {hitung }} 1.029$ lebih kecil daripada dari nilai $\mathrm{F}_{\text {tabel }}$ 5.14, hal ini menunjukkan bahwa tidak ada perbedaan bermakna pada peningkatan konsentrasi PEG 400 dalam formula patch natrium diklofenak. Berdasarkan kurva fluks pelepasan dari sediaan patch natrium diklofenak dihubungkan dengan peningkatan kadar PEG 400, nilai fluks pelepasan natrium diklofenak pada kadar PEG 20\% lebih besar daripada nilai fluks pelepasan natrium diklofenak pada kadar PEG 5\% dan 10\%. Hal lain yang diperhatikan adalah konsistensi sediaan dengan kadar PEG 20\% adalah yang terbaik.

Tabel 2. Hasil pemeriksaan organoleptis sediaan patch Natrium Diklofenak pada berbagai kombinasi polimer

\begin{tabular}{cccc}
\hline Sediaan & Konsistensi & Warna & Bau \\
\hline Formula 1 & Kaku, agak rapuh & Putih transparan & Tidak berbau \\
Formula 2 & Kaku, agak rapuh & Putih transparan & Tidak berbau \\
Formula 2 & Kaku, agak rapuh & Putih transparan & Tidak berbau \\
\hline
\end{tabular}
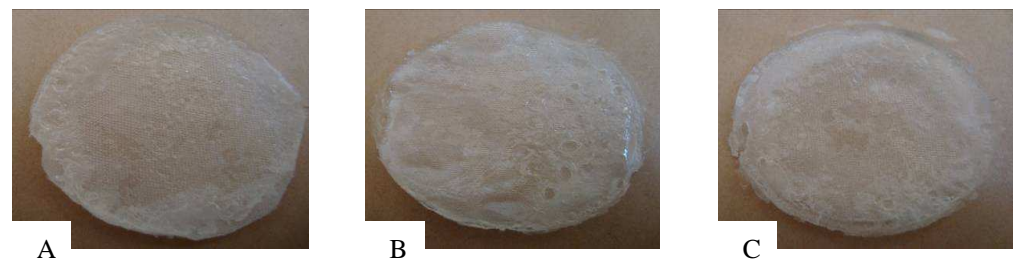

Gambar 1. Hasil patch Natrium Diklofenak secara fisik, A=formula 1; B= formula 2; $C=$ formula 3 
Pengaruh kadar polietilen glikol (peg) 400 terhadap Pelepasan natrium diklofenak dari sediaan Transdermal patch type matriks

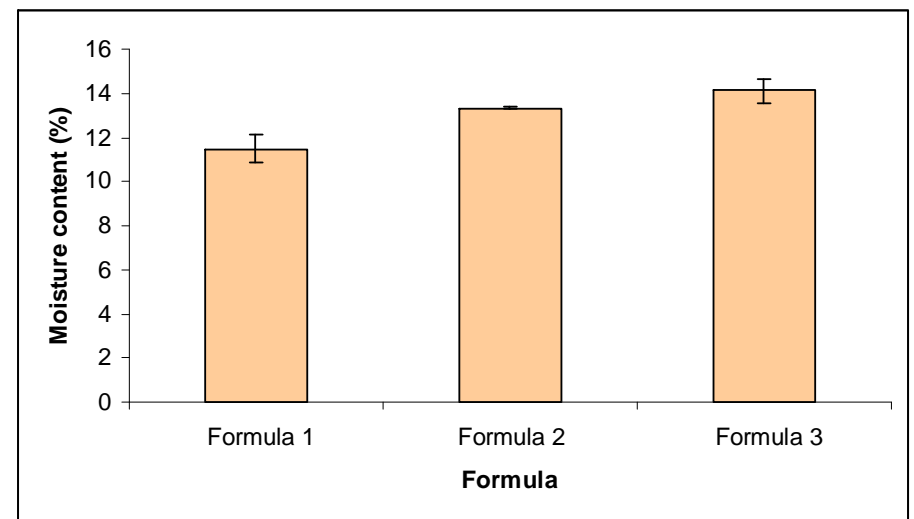

Gambar 2. Histogram moisture content patch natrium diklofenak

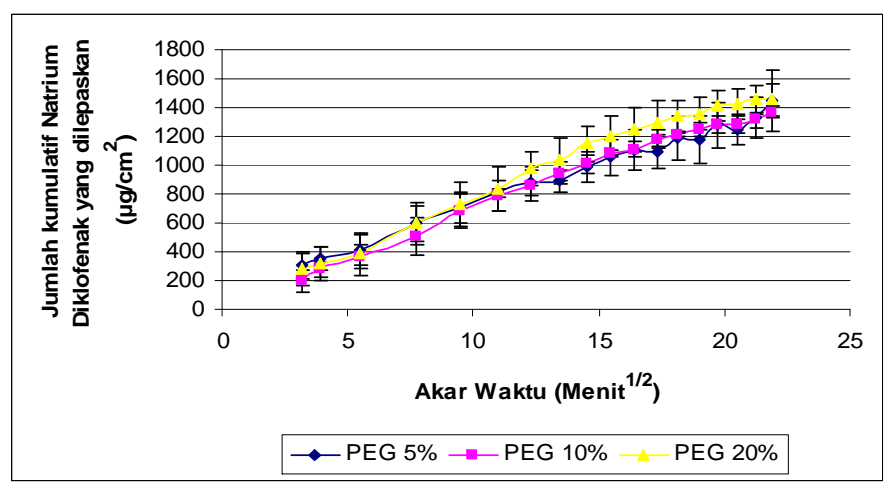

Gambar 3. Kurva hubungan antara akar waktu $\left(\right.$ menit $\left.^{1 / 2}\right)$ vs jumlah kumulatif rata-rata $\pm S D\left(\mu \mathrm{g} / \mathrm{cm}^{2}\right) \mathrm{Natrium}$ Diklofenak yang dilepaskan dari patch matriks Natrium Diklofenak pada kombinasi polimer Etil selulosa (EC) N-20 - Polivinilpirolidon (PVP) K-30 6:4 pada konsentrasi PEG 5\%, 10\% dan 20\%

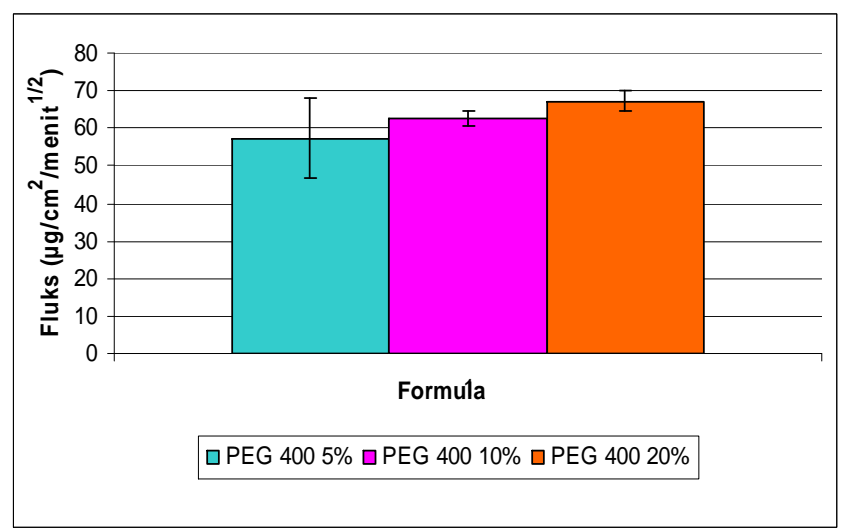

Gambar 4. Histogram Fluks $\left(\mu \mathrm{g} / \mathrm{cm}^{2} /\right.$ menit $\left.^{1 / 2}\right)$ dari Sediaan Patch Natrium Diklofenak pada konsentrasi PEG $5 \%, 10 \%$ dan $20 \%$ 
Pengaruh kadar polietilen glikol (peg) 400 terhadap Pelepasan natrium diklofenak dari sediaan Transdermal patch type matriks

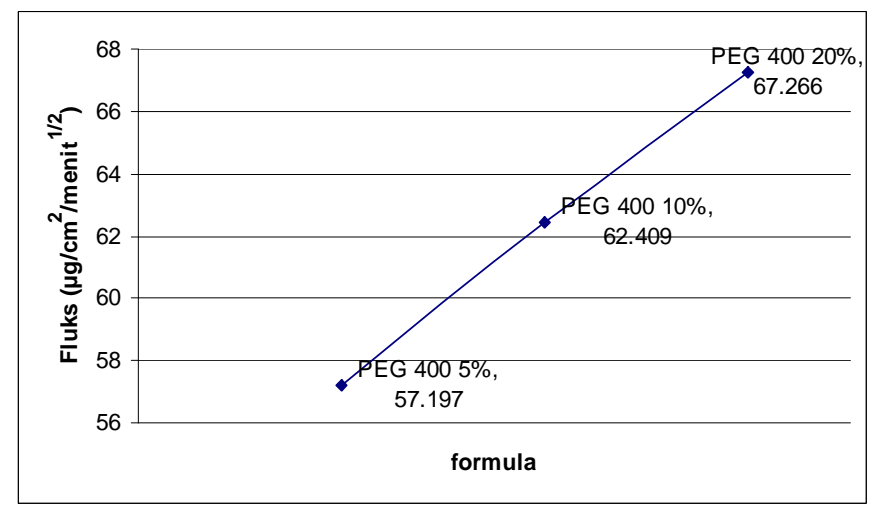

Gambar 5. Kurva Fluks $\left(\mu \mathrm{g} / \mathrm{cm}^{2} /\right.$ menit $\left.^{1 / 2}\right)$ dari Sediaan Patch Natrium Diklofen pada konsentrasi PEG 5\%, $10 \%$ dan $20 \%$

\section{KESIMPULAN}

Hasil pelepasan natrium diklofenak dari sediaan transdermal patch natrium diklofenak dengan plasticizer polietilenglikol (PEG) 400 pada kadar 20\% lebih besar daripada kadar 5\% dan $10 \%$.

\section{TERIMA KASIH}

Terimakasih kepada UP. Fakultas Farmasi Universitas Mulawarman atas bantuan dana penelitian, Laboratorium Farmasetika Fakultas Farmasi Universitas Airlangga atas bantuan fasilitas penelitian.

\section{DAFTAR PUSTAKA}

1. Chuasuwan, B.; Binjesoh, V.; Polli, J.E.; Zhang, H.; Amidon, G.L.; Junginger, H.E.; Midha, K.K.; Shah, V.P.; Stavchansky, S.; Dressman, J.B.; \& Barends, D.M. 2008,
Biowaiver Monographs for Immediate Release Solid Oral Dosage Forms: Diclofenac Sodium and Diclofenac Potassium. Journal of Pharmaceutical Sciences, DOI 10.1002/jps.21525, p.1-14

2. Kandavilli, S.; Nair, V.; \& Panchagnula, R. 2002, Polymers in Transdermal Drug Delivery Systems. Pharmaceutical technology, p. 62-80.

3. Kumar, R.; \& Philip, A. 2007, Modified Transdermal Technologies: Breaking the Barriers of Drug Permeation via the Skin. Tropical Journal of Pharmaceutical Research, 6 (1), p 633-644

4. Nandi, I.; Bateson, M.; Bari, M.; \& Joshi, H.N. 2003, Synergistic Effect of PEG-400 and Cyclodextrin to Enhance Solubility of Progesterone. AAPS PharmSciTech, 4(1), p 1-5

5. Rathbone, M.J.; Hadgraft, J.; \& Roberts, M.S. 2002, Modified-Release Drug Delivery Technology, Marcel Dekker, Inc.; New York, Basel. p 471-498

6. Valenta, C.; \& Auner, B.G. 2004, The Use of Polymers for Dermal and Transdermal Delivery. European Journal of Pharmaceutics and Biopharmaceutics, 58, p.279-289. 